\title{
TINJAUAN GAME PUZZLE VICTORIAN MYSTERIES: WOMAN IN WHITE MENGGUNAKAN PENDEKATAN SEMIOTIKA
}

\author{
Wieke Tasman, Elizabeth Wianto \\ (Email: wietasm@gmail.com) \\ Program Studi Sarjana Desain Komunikasi Visual \\ Fakultas Seni Rupa dan Desain \\ Universitas Kristen Maranatha \\ JI. Prof. drg. Surya Sumantri MPH No. 65, Bandung, Indonesia
}

\begin{abstract}
ABSTRAK
Game sebagaimana telah menjadi media yang umum di masyarakat, kemunculan idenya dapat berasal dari mana saja. Hal ini dibuktikan dengan perancangan game berjudul "Woman in White" yang terinspirasi dari novel Wilkie Collins. Popularitas novel berjudul sama yang kemudian setelah seratus lima puluh tahun telah teradaptasi dan muncul dengan makna yang baru, menjadikan game-nya muncul sebagai rancangan baru dari hiburan yang aktual. Tulisan ini mencoba menganalisis kesesuaian aspek yang ada dalam novel yang dipergunakan lebih lanjut sebagai aset formal maupun non-formal dalam game melalui pendekatan semiotika visual berdasarkan teori klasik dari Saussure, Peirce, dan Barthes. Adapun hasil analisis bertujuan untuk menunjukkan bahwa sebuah game yang dirancang berdasarkan inspirasi novel atau kisah populer perlu tetap setia terhadap kisah tersebut walaupun media ini tidak memiliki storytelling yang utuh.
\end{abstract}

Kata Kunci: legenda urban; permainan; puzzle; semiotika

\section{ABSTRACT}

Game already became common media in any society. It's ideas could be from anywhere. This example is proven in game titled Woman in White. Adapted from Wilkie Collin's sensational novel. Mr Collin's novel in similar title was very popular then, though after one hundred and fifty years already adapted dan raised into newer meaning. This new meaning of 'Woman in White' makes the game became new media design and still entertains its audiens. This study, try to analize similar aspect in novel that used in this game as formal or nonformal assets, using visual semiotics. Precisely using classic theory from Saussure, Peirce and Barthes. The results of the analysis aim to show that a game designed based on novel inspiration or a popular story needs to remain true to the story even though this media does not have a full story telling.

Keywords: game; puzzle; semiotics; urban legends 


\section{PENDAHULUAN}

Game Victorian Mysteries: Woman in White (WiW) adalah game yang dikembangkan oleh Freeze Tag dan diluncurkan oleh Big Fish Games, sebuah perusahaan penyedia software casual game asal Amerika Serikat. Game casual yang dipublikasikan oleh perusahaan yang berdiri sejak tahun 2002 ini, dapat dimainkan gratis secara online melalui jejaring sosial, ataupun dapat dimainkan secara offline melalui sistem penjualan game yang terintegrasi bagi pengguna personal computer berbasis windows, iOS dan smart phone dengan spesifikasi tertentu.

Game WiW ini merupakan game Hidden Object Game yang berjenis puzzle dan dikombinasikan dengan game petualangan yang memiliki ending sekali jalan atau tanpa meta plot. Alur dari game ini sesuai dengan novel berjudul sama yang diadaptasinya yaitu Woman in White.

Woman in White adalah novel karya Wilkie Collins yang terbit pertama kali oleh Sampson Low Publisher pada tahun 1860 di Inggris. Novel ini merupakan arketipe Sensation Novel, yaitu jenis prosa populer di Inggris Raya sekitar tahun 1860-1870 yang ditandai tema penculikan, pengekangan, terapi kejiwaan dengan latar belakang aristokrasi abad ke-19 di Inggris. Sudut pandang penulisan novel ini adalah epistolari, yaitu menggunakan sudut pandang orang pertama yang memperlihatkan berbagai catatan, jurnal dan dokumen sebagai pendukung jalan cerita. Istilah sensation novel, menurut Matthew Sweet (2014, https://www. bl.uk /romanticsand-victorians/articles/sensation -novels, 25 Mei 2016, pkl 20.58 WIB) lekat dengan novel Woman in White, karena novel ini menawarkan pengalaman yang lebih kaya dari sekedar pengalaman sensasional sesaat.

Pengalaman ini masih berdasarkan pendapat Sweet (2014), termasuk di dalamnya pengenalan terhadap kondisi sakit jiwa, pencurian identitas, dan rahasia keluarga yang tidak menentu khas abad ke-19. Efek kebaruan yang ditawarkan oleh novel ini mengakibatkan novel Woman in White menjadi salah satu novel yang terlaris di zamannya, sehingga segala sesuatu yang dikaitkan dengannya berkaitan dengan kultur populer pada saat itu. 


\section{Ringkasan Novel Woman in White}

Novel ini dimulai dari kisah kedatangan Walter Hartright sebagai guru lukis bagi anak-anak gadis keluarga Fairlie, yaitu Laura Fairlie dan Marian Halcombe. Dari nama belakang yang berbeda, sudah dapat diketahui bahwa Marian dan Laura adalah saudara tiri berbeda ayah. Ketika dalam perjalanan menuju tempat kerjanya yang baru, Walter Hartright sempat bertemu dan menolong seorang wanita muda yang tampak depresi, ia mengenakan gaun berwarna putih dan tampaknya sedang melarikan diri.

Keesokan harinya di rumah kediaman keluarga Fairlie dengan kepala keluarganya yaitu Frederick Fairlie, paman Laura, Walter Hartright bertemu dengan calon muridnya yaitu Laura dan Marian. Walter melihat bahwa secara fisik, Laura sangat mirip dengan wanita berbaju putih tersebut, yang kemudian diketahui ternyata bernama Anne Catherick.

Singkat cerita Walter dan Laura memiliki ketertarikan satu sama lain secara romantis, tetapi karena janji Laura kepada ayahnya untuk menikahi Sir Percival Glyde maka jalinan cinta ini terputus dan keduanya berpisah.

Laura menikahi Sir Percival Glyde dan pergi ke Italia, sedangkan Walter Hartright mengikuti ekspedisi di Honduras. Enam bulan kemudian, suami istri Glyde kembali ke rumah keluarga Fairlie di Hampshire yang bernama Blackwater Park. Kepulangan mereka ditemani oleh teman Sir Percival Glyde yang bernama Count Fosco, yang juga merupakan suami dari bibi Laura dan Marian. Dalam perjalanan cerita, diketahui bahwa Count Fosco dan Sir percival Glyde memiliki agenda tersembunyi, hal ini berangsur-angsur terkuak lewat narasi dalam novel. 


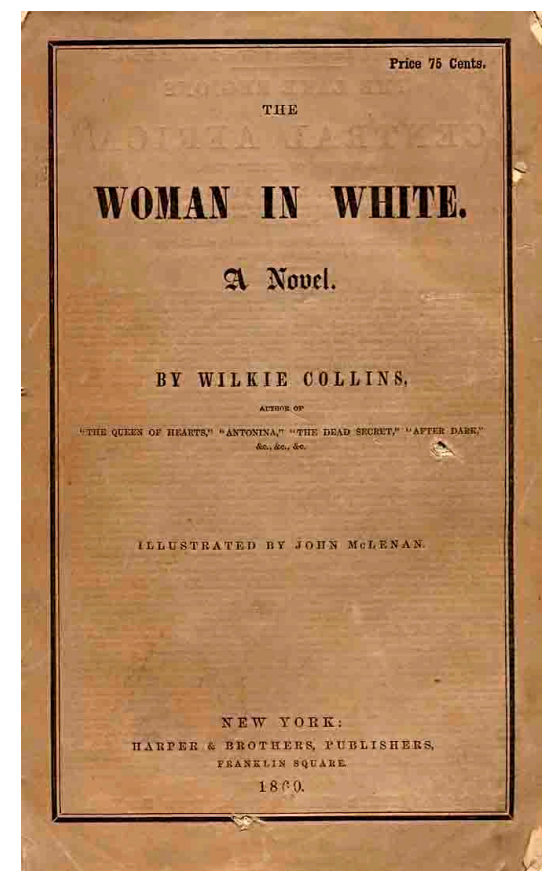

Gambar 1. Cover Buku Woman in White edisi 1 di Amerika Serikat oleh Penerbit Harpers Sumber: http://www.wilkie-collins.info/books_woman_white.htm

Secara perlahan, Marian yang merupakan pahlawan wanita dari novel ini menguak misteri dengan bantuan Walter Hartright dan Anne Catherick, sehingga pada akhir cerita keburukan Sir Percial Glyde dan Count Fosco yang hendak menguasai warisan Laura Fairlie dapat dihentikan. Tentunya seperti kisah-kisah yang berakhir bahagia, Laura dan Walter menikah, dan hidup bahagia bersama putra mereka dan Marian di Limmeridge. (ringkasan novel disarikan dari berbagai sumber)

\section{Game Woman in White}

Sama seperti alur cerita pada novelnya, Game Woman in White mengikuti jalinan cerita yang dibagi menjadi enam stage yaitu: (1) Arrival at Limmeridge; (2) The Gazebo; (3) Return to Limmeridge; (4) The Chapel; (5) Blackwater Park; dan (6) The labyrinth.

Game WiW menggunakan setting abad ke-19, lebih tepatnya pada periode Victorian di Inggris. Tema populer pada saat itu adalah Gothic Horror, atau Sensational Novel, hal ini menjadikan game dengan selaras dapat dikombinasikan dengan kasus pemecahan misteri. Sesuai dengan tujuan dalam game, misteri secara bertahap diselesaikan melalui upaya penemuan berbagai 
benda yang tersembunyi. Setiap benda yang ditemukan, secara berurutan muncul sesuai dengan perjalanan narasi cerita mengikuti arahan peta lokasi Limmeridge.

Secara keseluruhan, panjangnya waktu yang diperlukan untuk memecahkan keseluruhan misteri dan menyelesaikan game ini cukup singkat. Hal tersebut ditunjang oleh ketidaktersediaan mini game sebagaimana sering ditampilkan pada game-game petualangan lainnya. Seluruh level dalam game ini adalah level boss, adapun stage selanjutnya akan terbuka, setelah teka-teki utama - yang biasanya berupa bagaimana cara untuk membuka 'portal atau pintu tertentu' - dipecahkan.

Secara visual, game ini menampilkan gambar-gambar tidak bergerak (tidak memiliki sprite), pengetahuan mengenai maksud gambar, muncul secara naratif, baik secara lisan (lewat audio yang diperdengarkan), maupun tulisan berupa balon bicara. Tampilan dari gambar yang ada diwujudkan secara realis dengan perwujudan tampilan asli benda dan manusia di dunia nyata dengan menggunakan teknik digital painting untuk manusia dan lingkungan dan 3 Dimentional modeling untuk obyek-obyek sebagai aset game yang dicari.

Game WiW sifatnya akan menjadi usang ketika level terakhir berhasil dipecahkan, apalagi bagi gamer yang sudah membaca bukunya akan dapat memperkirakan kapan game ini akan berakhir. Sebagaimana dituliskan sebelumnya, maka alur cerita berjalan satu arah tanpa meta plot, sehingga setelah berhasil menyelesaikan teka-teki yang ditawarkan maka biasanya pemain tidak akan mengulang permainan ini.

Namun demikian, hal tersebut adalah lumrah didalam game dengan jenis puzzle, enam stage yang tidak termasuk introduksi, menjadikan game ini cukup singkat untuk diselesaikan. Dengan demikian dapat diperkirakan bahwa game ini diperuntukkan bagi pemain yang pengisi waktu luang atau casual gamers yang tidak menuntut perkembangan game menjadi 'simulasi' kehidupan nyatanya sehari-hari.

\section{Cara, Aturan, Tujuan, Reward dan Punisment pada Game Woman in White}

Cara bermain dalam game ini adalah sesuai dengan kemampuan console pendukungnya yaitu berupa komputer personal atau laptop dengan bantuan mouse sebagai pengatur segala macam 
gerakan maupun pilihan. Dasar operasi permainan ini adalah satu pemilihan tunggal pada satu waktu yang bersamaan. Melalui aturan pemberian perintah tunggal tadi, pemain dapat: (1) mengambil alat yang tercecer; (2) meletakkan/ memasang alat dan bahan sesuai urutan pekerjaan dan (3) mengarahkan dirinya pada lokasi yang diinginkan. Ketiga jenis perintah tersebut dilakukan dengan klik kiri tunggal pada mouse terhadap area yang diinginkan, yang sudah dapat memenuhi semua jenis gerakan yang diperlukan pada permainan.

Tujuan permainan ini adalah untuk memecahkan misteri yang ada, mencari siapa wanita berbaju putih yang ditemui oleh Walter Hartright dan alasan ia menghilang. Misteri akan dapat dipecahkan dengan menemukan barang-barang yang disembunyikan (hidden object).

Sama seperti pada permainan sejenisnya, game ini dibagi menjadi dua mode, yaitu casual mode, yaitu mode yang memberikan berbagai kelonggaran petunjuk dan waktu yang tidak dibatasi, serta expert mode, yaitu mode yang melimitasi petunjuk dan waktu yang dihitung. Kedua mode dapat dipilih oleh pemain sebelum memasuki arena permainan sesuai dengan keahlian (atau preferensi) masing-masing. Melalui penyediaan dua mode yang berbeda otomatis memberikan punishment yang berbeda pada pemain yang bermain pada expert mode dan casual mode. Punishment pada expert mode meliputi: (1) habisnya waktu bermain; dan (2) tidak ada petunjuk mengenai apa yang perlu dilakukan untuk memecahkan puzzle yang muncul. Sedangkan pada casual mode, punishment tidak ditambahkan dengan pembatasan waktu.

Reward pada permainan ini baik pada casual mode maupun pada expert mode kurang lebih sama, yaitu akses untuk membuka stage selanjutnya, sehingga pada akhirnya dapat memecahkan misteri yang ada. Reward kecil disepanjang permainan adalah berupa alat-alat yang dapat dipergunakan untuk membantu pemain meneruskan permainan, seperti misalnya: tali, kunci, cat, telur, tangga, kayu, linggis dan lain sebagainya.

Game WiW, merupakan game puzzle yang sarat dengan gambar, dapat dimainkan tanpa suara dengan spesifikasi komputer yang rendah karena gambarnya tidak memiliki pergerakan dan tidak memiliki skoring kuantitatif sebagai penilai keberhasilan pemain. Analisis game ini akan dilakukan menggunakan semiotika secara visual, untuk mengetahui preferensi pembuat game 
dalam menginformasikan instruksi yang dapat dengan mudah dipahami melalui gambar, dan kepatuhan terhadap novel yang menjadi acuannya.

\section{METODE PENELITIAN}

Analisis Semiotika dilakukan pada beberapa user interface pilihan dalam game, yaitu pada Menu Utama Game. Menu Utama - terutama pada game online yang tidak memiliki media promosi lain berupa poster ataupun software yang dijual dalam bentuk fisik, pada umumnya bertindak sebagai interface awal yang bersinggungan dengan pemain. Tampilan Menu Utama menentukan tertarik atau tidaknya pemain untuk melanjutkan permainan yang ditawarkan. Untuk itulah, Menu Utama game ini dipilih, karena perannya yang harus dapat memperlihatkan tujuan, situasi, setting tempat dan waktu.

Maksud pengambilan frame Menu Utama adalah untuk memperlihatkan situasi keseluruhan dari game berbasis novel populer yang kandungan tanda didalamnya akan dianalisa secara bertahap menggunakan beberapa teori semiotika.

Tahapan penerapan semiotika yang dimaksud adalah:

1. Mengurai tanda dan yang ditandainya sesuai dengan teori Semiologi Ferdinand de Saussure, yaitu (a) signifier/ penanda dan (b) signified/ tinanda,

2. Menggunakan teori Semiotika Peirce untuk mengetahui jenis gambar atau obyek direpresentasikan. Charles Sanders Peirce yang memunculkan term Semiotika, dan membagi subyek menjadi tiga komponen dasarnya, yaitu (a) tanda itu sendiri/ icon; (b) sesuatu yang memiliki hubungan sebab akibat dengan tanda itu/ indeks, dan (c) interpretasi secara arbitrer dari kemunculan tanda yang dimaksud/ simbol. (Santoro, 2014: 267)

3. Mengetahui tingkatan tandanya, sesuai dengan teori Roland Barthes (dalam Tinarbuko, 2008: 15) yaitu: (1) denotatif dan (b) konotatif. Makna denotatif merupakan penjelasan harafiah, eksplisit dan universal; sedangkan makna konotatif adalah penjelasan dengan terkontaminasi 'makna' yang sifatnya implisit dan bisa jadi berubah-ubah tergantung pengalaman dan pengetahuan seseorang yang menguraikan tingkatan tanda tersebut (Piliang, 2010) 
4. Menyimpulkan prinsip tanda yang dikaitkan dengan tujuan pembuatan game yang secara kreatif harus dapat menyampaikan maksudnya oleh pembuat game berupa mitos dan metonim selaras dengan signifikansi tanda Roland Barthes. (dalam Tinarbuko, 2008: 15).

Metonymy atau Metonim dikenal juga dalam majas perbandingan di dalam Bahasa Indonesia yang secara keseluruhan mengandung prinsip dasar yang sama seperti dalam semiotika. Metonim dapat diartikan sebagai gaya bicara yang melibatkan sebuah penanda untuk menggantinya dengan penanda yang lain yang secara langsung memiliki hubungan dan asosiasi dengannya. (Chandler, 2002. http://www.aber.ac.uk/media/Documents/S4B/sem-gloss.html\#M)

Kaitan makna konotatif yang dikaitkan dengan metonim dilakukan supaya penyampaian pesan dapat lebih bermain, menarik, tidak selalu harus harafiah karena ada proses menafsir dimana semakin luas pengalaman dan pengetahuan seseorang maka pesannya semakin lengkap tertangkap.

Penelitian menggunakan pendekatan semiotika sesuai dengan teori yang dipaparkan diatas untuk mengkonfirmasi bahwa sebuah permainan digital yang terinspirasi dari kisah populer yang telah ada perlu mengatur rancangan visualisasi elemen formal maupun non formalnya, sehingga kisah yang diangkat dapat membantu calon pemain untuk dapat mengikuti alur permainan.

Mempermudah penjelasan, pada Gambar 1 adalah tampilan Menu Utama Game WiW, serta pada gambar 2 adalah Legends untuk mempermudah alokasi penunjukkan obyek yang dimaksud.

\section{PEMBAHASAN}

Uraian signifier dan signified pada Menu Utama Game WiW adalah sebagai berikut:

1. Signifier/ penanda dalam game ini adalah seluruh gambar serta suara yang dipaparkan berupa user interface dari game yang ditampilkan. Setiap signifier akan memiliki tujuan representasi yang berbeda, tergantung fungsi dari aset tersebut dalam game WiW. 
Seluruh signifier dirancang dengan memperhatikan konteks dan setting yang ada, yaitu: (1) Hendak menunjukkan bahwa sudut pandang dari dalam kamar yang bernuansa Victorian Art; (2) Kamar ini memiliki sebuah jendela yang memperlihatkan adanya sesosok wanita yang sesuai dengan judul game, yaitu wanita berpakaian putih; (3) Keselarasan penggunaan setiap obyek yang dipilih dan dipasang pada Menu Awal game ini menunjukkan awal game dapat diakses lebih lanjut.

2. Signified/ tinanda dalam game ini adalah seluruh maksud dan tujuan dari game berupa teka-teki, hidden object, untuk dipecahkan oleh pemain game. Melalui komposisi menu awal, maka gambar menu utama secara utuh menunjukkan awal dari permulaan memasuki game.

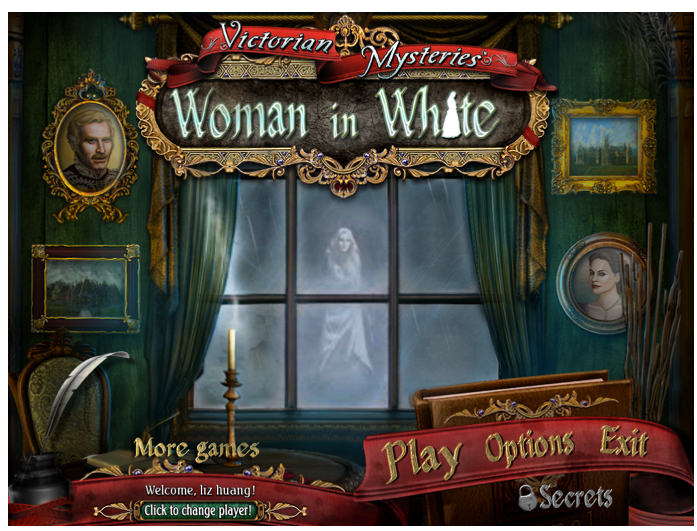

Gambar 2. Menu Utama Victorian Mysteries: Woman in White Sumber: Game WiW

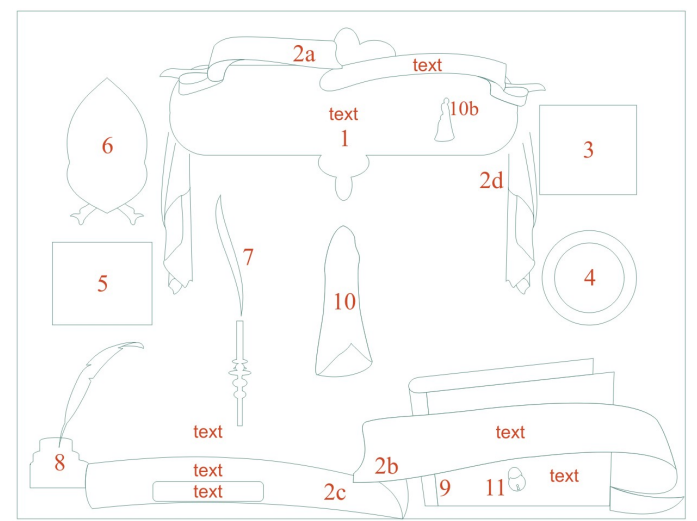

Gambar 3. Legends Menu Utama Victorian Mysteries: Woman in White Sumber: Hasil Penelitian 


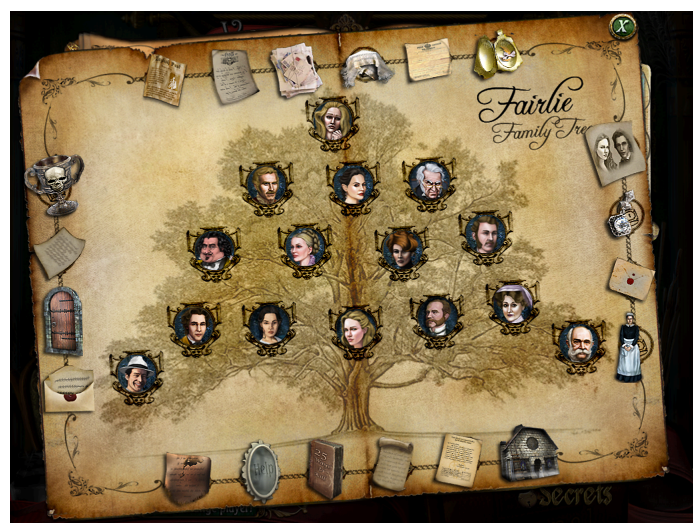

Gambar 4. Pohon Keluarga Fairlie Sumber: Game WiW

Jenis gambar atau obyek yang direpresen- tasikan berdasarkan teori Semiotika Peirce:

\section{Sebagai Ikon}

Komposisi layout dari Menu Utama terdiri dari tanda verbal dan tanda visual. Secara eksplisit, dapat dilihat tanda verbal yang terdiri dari: Victorian Mysteries, Woman in White, More games, Welcome (nama pemain), click to change player, Play, Options, Exit dan Secrets. Adapun tanda visual dapat terlihat berupa : (1) Bingkai penempatan judul game, (2a-d) drapery pita, vitrage dan gorden lengkap dengan penyangganya yang tampak terbuat dari bahan metal berwarna keemasan, (3) lukisan pemandangan di kanan atas, (4) lukisan atau foto seorang wanita di kanan bawah, (5) lukisan pemandangan di kiri bawah, (6) lukisan atau foto seorang wanita di kiri atas, (7) asap dari lilin yang apinya baru saja padam, (8) bak tinta dan pena bulu, (9) separuh bagian atas dari buku yang tertutup, (10) seorang wanita diluar jendela kaca berpakaian putih, (10b) siluet wanita dalam posisi menyamping sebagai pengganti huruf ' $i$ ' pada judul game, (11) gembok terkunci disebelah kiri tulisan 'Secrets' dan background pelengkap berupa kursi berbantalan, hiasan berbentuk buluh kayu/ bambu, coffee table bundar, serta pilar/ pilaster penunjang (nampaknya berkepala Corinthian yang dimodifikasi) di bagian kanan gambar.

Secara keseluruhan komposisi yang diperlihatkan bersifat statis dan simetris secara bilateral, walaupun tidak persis sama, tapi bila dibagi menjadi dua bagian yang sama antara bagian kiri dan kanan, maka setiap item yang ada memiliki padanan pada setiap bagian yang lain. Otomatis satu-satunya icon yang tidak memiliki padanan dan menjadi focal point adalah 
seorang wanita diluar jendela yang berpakaian putih. Warna-warna yang muncul disini diwarnai secara gradatif menggunakan beberapa warna coklat, hijau lumut, merah, coklat keemasan, putih dan nuansa kebiruan.

\section{Sebagai Indeks}

Tanda berupa indeks terdapat pada Menu Utama dianalisa secara synchronic, kekecualian dilakukan terhadap asap yang timbul setelah lilin mati yang otomatis dianalisa secara diachronic. Komposisi yang sama menunjukkan bahwa welcoming screen ini menunjukkan berbagai instruksi awal yang perlu diperhatikan pemain. Dengan melihat interface awal ini, pemain dapat mengetahui bahwa nama pemain yang tercantum adalah yang sedang melakukan progres pemecahan misteri. Animasi yang menampilkan lilin yang menyala kemudian padam juga menunjukkan bahwa setting Menu Utama dilakukan ketika malam hari (atau menjelang dini hari melihat kabut dan warna kebiruan yang menjadi nuansa utama gambar), padamnya lilin menunjukkan situasi yang mencekam dan berlalunya waktu sehingga keadaan menjadi semakin genting bagi pemain agar cepat memecahkan misteri yang ada. Mengenai 'misteri' yang harus dipecahkan sendiri terindikasi dari wanita berbaju putih yang berada dan menjadi fokal poin diluar ruangan, jelas misteri yang perlu dipecahkan berhubungan dengan sosok wanita berbaju putih tersebut, apalagi sudah secara eksplisit ditekankan pada judul game. Judul pengantar (Victorian Mysteries) menunjukkan bahwa misteri ini berlangsung pada periode tertentu, yaitu periode Victorian di Inggris yang berlangsung pada tahun 1837 s.d 1901 sesuai masa pemerintahan Ratu Victoria. Komposisi gambar pada Menu Utama secara keseluruhan yang simetris, tenang dan statis menunjukkan keadaan 'permukaan' yang menghanyutkan dan mengindikasikan ada sesuatu yang tidak sesuai namun belum terdeteksi dengan lebih jelas.

\section{Sebagai Simbol}

Simbol pada komposisi Menu Utama muncul secara integratif antara item-item yang disusun sedemikian menjadi komposisi yang ditampilkan, namun simbol berdasarkan item yang berdiri sendiri dapat diuraikan sebagai berikut:

1. Gembok tertutup (11), disini gembok yang tertutup menyimbolkan adanya suatu rahasia yang tertutup rapat, sebenarnya hal ini secara eksplisit sudah dinyatakan oleh tulisan verbal 'Secrets' disebelah kanannya. Secara eksplisit, tulisan tersebut menyatakan bahwa 
rahasia yang tersimpan sifatnya adalah majemuk, banyak dan kemungkinan besar saling berkait, yang mana semuanya masih tersembunyi oleh simbol gembok yang masih tertutup.

2. Lukisan pria (6), wanita (4) dan komposisinya dengan wanita muda di luar ruangan, dapat menjadi simbol bahwa ketiganya berkaitan. Simbol yang jelas menunjukkan bahwa kedua lukisan menunjukkan strata yang setara walaupun yang pria lebih berkuasa. Hal ini ditunjukkan oleh ukuran dan posisi lukisan pada dinding yang sama, namun kuasa pria nampak diatas wanita karena posisi lukisannya dipasang lebih tinggi daripada wanita.

Dengan ukuran yang sama tampaknya ada hubungan yang sepadan antara keduanya, bisa jadi kepemilikan bersama dari tempat dimana kedua lukisan tersebut tergantung atau hubungan suami istri. Atribut yang menyertai kedua lukisan juga menunjukkan status kebangsawanan dimana yang pria menggunakan pakaian resmi, dan bercukur rapi, sedangkan yang wanita bermake up lengkap namun tidak menor, menggunakan kalung choker, serta tatanan rambutnya rapi diikat kebelakang dengan kesan bergelombang pada bagian depan namun tidak ada anak rambut yang jatuh menandakan ia bukan pekerja kasar. Adapun kaitan keduanya dengan penampakan wanita diluar ruangan masih belum jelas, walaupun ada dua hal yang dapat tersimbolkan dari posisi ketiganya, yaitu sebagai pemisah atau pemersatu kedua lukisan di dalam ruangan.

3. Pena bulu, bak tinta (8) dan keseluruhan komposisi menunjukkan bahwa setting tempat menunjukkan simbolisasi tingkat edukasi yang cukup tinggi, apalagi ditunjang oleh setting waktu pada periode Victorian, dimana tidak semua kalangan dapat menulis dan membaca.

4. Keseluruhan sintagma yang diperlihatkan pada komposisi Menu Utama menunjukkan bahwa game ini simbol dari sifat tenang, pemecahan masalah memerlukan kecerdikan dan kecermatan, oleh karena itu dapat diketahui bahwa game ini menitikberatkan pada konsentrasi dan ketelitian, bukan kecepatan dan ketangkasan.

Pada menu utama game WiW, makna denotatif yang muncul adalah komposisi atribut yang umum muncul dalam kalangan terpelajar dan cukup terpandang pada periode Victorian di 
Inggris, seperti: pena bulu, lukisan realis, naturalis atau romantik, drapery kain yang menjadi vitrage dan gorden khas periode Victorian serta penataannya yang teratur. Untuk latar belakang, tampak bahwa suasana dibangun untuk memperlihatkan setting dimalam hari (atau dini hari melihat warnanya yang bernuansa kebiruan). Matinya lilin sebagai penerangan buatan - satu-satunya yang nampak sebelum datangnya fajar, menjadikan suasana menjadi lebih gelap dan menjadikan kehadiran wanita berbaju putih di luar jendela dapat terlihat dengan sangat jelas bagi calon pemain game.

Sedangkan makna konotatif yang muncul pada komposisi Menu Utama adalah suasana yang cukup mencekam karena lilin sebagai satu-satunya penerangan di malam hari yang nampak pada gambar padam. Secara keseluruhan komposisi dapat dibagi dalam setting yang berlapis, yaitu diluar dan didalam ruangan. Komposisi dalam ruangan tampak teratur, harmonis dan menunjukkan tanda-tanda ketenangan layaknya keluarga bangsawan, atau keluarga berekonomi mapan dan berkelas pada periode Victorian, sedangkan komposisi diluar ruangan tampak lebih tidak bersahabat karena cuaca yang dingin, suasana dini hari yang tenang namun mencekam tampak membuat sosok wanita berbaju putih yang ada tampak tidak nyaman. Pun gestur wanita berbaju putih yang sedang mendekap tangannya kedada - tanda sikap defensif, dengan pakaiannya yang nampak menutupi seluruh tubuhnya membuat situasi menjadi kontras antara komposisi dalam dan luar ruangan. Dari ketiga wajah yang nampak pada Menu utama, tidak tampak suatu sifat yang menunjukkan ciri-ciri kehangatan dalam keluarga, namun kedua lukisan menunjukkan kesan noble, berbeda dengan wanita berbaju putih diluar ruangan yang tampak tanpa ekspresi - mungkin karena sedang dilanda kebingungan. Dengan demikian, dari perbandingan kesan yang nampak antara komposisi didalam dan diluar ruangan, muncul makna konotasi berupa kondisi yang tidak ideal antara keseluruhan komposisi sehingga menyisakan suatu pertanyaan besar yang reflektif dengan makna game secara keseluruhan yaitu 'misteri'.

Pada dasarnya, mitos adalah tanda konotatif pada sistem pemaknaan tataran kedua yang dibangun di atas sistem lain yang ada sebelumnya (Sobur: 2009. Pg. 68 - 71). Sistem signifikansi tingkat pertama atau yang disebut dengan makna denotasi menurut Barthes, justru lebih terasosiasi dengan ketertutupan makna. Mitos menurut Barthes berfungsi untuk 
mengungkapkan dan memberikan pembenaran nilai dominan yang berlaku dalam periode tertentu.

Berdasarkan makna konotatif yang telah dipaparka pada poin sebelumnya, diketahui bahwa ada suatu misteri yang muncul - bukan karena game tersebut mengandung kata lateral 'Mystery', tetapi karena komposisi dan penggunaan warna yang mengkontraskan keberadaan setting di dalam dan diluar ruangan. Sebagaimana diketahui sebelumnya, mitos merupakan konstruksi budaya disekitarnya, maka makna tersebut dapat dikaitkan dengan setting pada periode Victorian.

Periode Victorian, dapat dikatakan sebagai sebuah periode pemerintahan yang didukung oleh revolusi industri. Hal ini ditandai dengan peningkatan perekonomian, peningkatan kesenjangan sosial antara kamu buruh dan pemilik pabrik, serta adanya kemapanan ekonomi bagi kalangan tertentu.

Di samping itu, periode ini juga muncul preferensi kembali terhadap arsitektur Gothic yang disebut sebagai Gothic Revival, dan sebagaimana yang diketahui bersama, istilah Gothic ini juga merambah pada jenis literatur tertentu yang berkisah seputar kisah horor (Frankenstein dan Dracula), detektif (Sherlock Holmes), kisah-kisah fantasi (Peter Pan dan Peter Rabbit), Kisah Petualangan (Tom Sawyer) dan kisah roman bertemakan feminisme (Pride and Prejudice). Adapun kisah-kisah literatur yang ada tersebut, selain karena pemikiran penulis yang piawai, juga tentunya dilandasi oleh observasi terhadap kejadian-kejadian di sekitarnya, di antaranya adalah pembunuhan serial oleh Jack The Ripper pada tahun 1888, kemajuan pengetahuan dan teknologi, mulai bangkitnya gerakan Feminis walaupun sangat terbatas, serta kemajuankemajuan lain dalam bidang politik dan sosial sehingga era ini oleh Miller (http://www.victoriaspast.com/FrontPorch/victorianera.htm, Diakses tgl 28 Mei 2017 pkl 18.50 WIB) disebut oleh sebagai Second British Renaissance.

Kaitannya pemaparan di atas mengenai sekilas periode dengan analisis mitos adalah bahwa 'misteri' yang muncul sebagai tanda dihubungkan secara langsung dengan konteks sosial, sehingga dapat diketahui bahwa Woman in White atau White lady atau Weeping Woman, adalah suatu istilah umum yang mengacu pada legenda urban yang populer. Khususnya di 
Inggris, Woman in White sering diasosiasikan dengan arwah wanita muda yang kerap diasosiasikan dengan tragedi pengkhianatan oleh pasangannya yang tidak setia. (https://exemplore.com/para normal/The-Woman-in-White-A-Legend, Diakses tgl 28 Mei 2017, pkl 19.08 WIB)

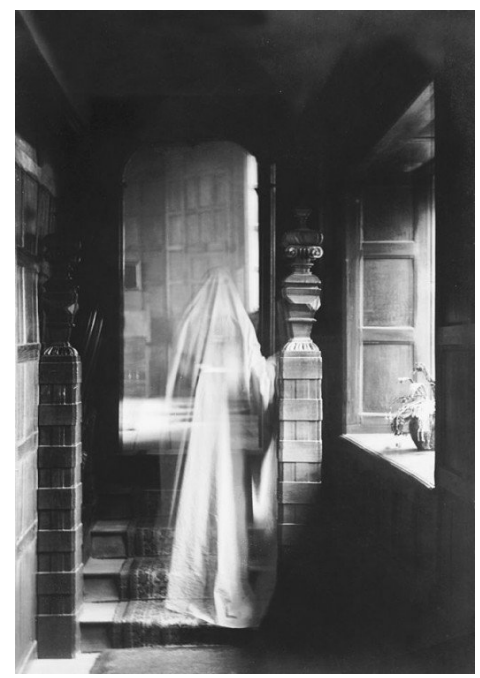

Gambar 5. Penggambaran Woman in White secara Klasik Sumber: https://exemplore.com/paranormal/The-Colour-of-Ghosts

Penggunaan mitos Woman in White menaturalisasi suatu keadaan yang tidak biasa, sehingga menggeneralisir sosok wanita berbaju putih yang muncul sebagai seorang sosok yang misterius.

Wilkie Collins dengan cermat menggunakan istilah Woman in White yang merupakan mitos yang sudah dikenal dalam masyarakat tanpa memberikan penjelasan lebih lanjut apakah sosok ini merupakan stereotyping yang beredar. Pada awal kemunculan novelnya, terutama di Inggris, setiap orang yang kurang lebih mengalami situasi serupa kemungkinan besar dapat mengapresiasi misteri wanita berbaju putih ini dengan cara yang mirip, namun merujuk pada masa kini, game WiW yang dibuat lebih dari 150 tahun setelah novelnya beredar - walaupun setting dan visualisasinya diusahakan seotentik mungkin, tidak semua audiens memiliki pengalaman dan pengetahuan yang sama mengenai konteks serupa sehingga kadar pesan yang hendak disampaikan belum tentu sama. Hal ini mengukuhkan kualitas mitos, seperti yang dikutip dari Barthes yaitu: "diketahui bahwa mitos tidak menyembunyikan apapun dan tidak memamerkan apapun, ia hanya mendistorsi, segala sesuatu terjadi seolah-olah gambar tersebut 
secara alamiah melahirkan konsep" (2004, h. 186),. Pernyataan pada kutipan terakhir mengantar mitos menjadi ideologi.

Dalam kasus ini, mitos Woman in White, yang diidentifikasikan sebagai misteri periode Victorian menjadi penanda dari sistem keyakinan bahwa adanya keadaan yang tidak aman, perlu dipecahkan dan dicari solusinya. Dengan demikian, ideologi yang secara tingkatan tandanya adalah signifier pada tataran kedua dapat dirumuskan sebagai: Aspek penting bagi pemain game untuk memecahkan misteri yang ada dalam game Victorian Mysteries: Woman in White.

Metonim pada game WiW ditemukan pada komposisi Menu Utama yang merupakan pars pro toto dari keseluruhan game. Game yang ada, juga merupakan pars pro toto dari novel secara keseluruhan dan tentu saja merupakan sepenggal atau secuplik kisah dalam periode Victorian yang sampai sekarang dapat dikatakan sebagai salah satu periode pemerintahan - dalam satu penguasa, yang terjaya dalam bidang ekonomi di Britania Raya. Sebagai sebuah metonim, maka frame Menu Utama berusaha mewakili keseluruhan pesan yang hendak ditampilkan dalam frame tunggal. Prinsip substitusi Metonim yang digunakan pada tampilan komposisi Menu Utama adalah sebagai Object for User, Substance for Form dan Place for Person yang dapat diuraikan sebagai berikut:

1. Object for user, tampak pada: (1) bingkai dekoratif untuk preferensi visual pada periode Victorian; (2) drappery vitrage dan pita untuk kemapanan ekonomi yang dimiliki pemilik tempat; (3), (5) lukisan bergaya realis, romantik atau naturalis untuk berupa nilai estetika klasik; (4), (6) lukisan atau potret diri untuk status kepemilikan; (8) pena bulu untuk keterpelajaran pengguna; (9) kitab yang tertutup untuk informasi yang tersimpan dan (11) gembok yang tertutup untuk rahasia-rahasia yang disembunyikan.

2. Substance for Form, tampak pada: (7) lilin yang mati dalam keadaan batang lilin yang masih panjang dengan keadaan malam hari untuk kondisi kesengajaan atau angin malam yang mematikan lilin (ketidaknyamanan) dan Tipografi yang merupakan parasignal berupa tulisan tangan dengan stem tebal tipis untuk tulisan yang berkesan klasik, pembuatannya secara manual menggunakan pena bulu atau alat kaligrafi.

3. Place for Person, tampak pada: (10) penempatan wanita berbaju putih diluar untuk diskriminasi yang diterimanya karena sesuatu hal; keseluruhan latar belakang penunjang 
(kursi berbantalan, coffee table yang terawat, sepenggal pilaster/ potongan pilar berkepala Corinthian) untuk status kebangsawanan pemilik dengan gaya hidup kelas atas.

\section{PENUTUP}

Melalui analisis frame Menu Utama yang dianggap mewakili game secara keseluruhan, dapat disimpulkan bahwa game ini secara visualisasi mengikuti secara patuh paradigma yang ada sesuai novel yang menginspirasinya. Warna, ornamen, atribut dan segala penyajian ditampilkan mengikuti kondisi otentik yang menyertai setting novel populer berjudul sama. Kepatuhan ini juga ditampilkan dari visualisasi yang tidak menampilkan visualisasi yang serba canggih dan bersifat futuristis seperti tampilan tiga dimensi yang memunculkan banyak fitur. Dari tampilan pada menu utama, diketahui bahwa game menawarkan suatu teka teki yang perlu dipecahkan secara cerdas dan cermat. Lebih lanjut sesuai dengan sifat game yang sekali jalan, maka game ini tidak menawarkan fitur yang mubazir seperti penilaian secara kuantitatif, karena pada dasarnya setelah misteri dipecahkan maka permainan ini menjadi usang.

Berdasarkan pendekatan semiotik yang dilakukan, maka diketahui bahwa game dan novel yang menginspirasinya saling mengisi, dengan cerdik pemanfaatan urband legend mengenai Woman in White yang telah dibuat menjadi cerita oleh Collins, serta pembuat game yang mentransformasikan mitos yang ada menjadi konsep dasar yang bertindak sekaligus sebagai judul pengantar game yaitu "Victorian Mysteries". Lebih lanjut diketahui bahwa ideologi yang dirunut dari mitos tersebut menjadi daya tarik terselubung terhadap pemain dengan berbagai tanda yang ada memiliki pesan 'penting untuk memainkan game ini dan memecahkan misterinya'. Dengan demikian dapat disimpulkan bahwa ideologi di sini dapat bertindak sebagai konsep komunikasi tanpa verbal untuk pembuatan game.

Game sebagai sebuah produk desain komunikasi visual perlu dengan cepat menyampaikan pesan. Kreativitas penyampaian pesan yang sebenarnya kompleks dilakukan oleh pembuat game pada Menu Utama berupa penerapan Metonim, keputusan ini adalah tepat mengingat game ini tidak memiliki media promosi lain sehingga interface awal inilah kontak pertama dan penentu apakah pemain hendak meneruskan atau berhenti bermain. 
Kepatuhan pembuat game untuk mengutamakan penggunaan visual yang mudah dikenali dan setia terhadap novel maupun urband legend yang telah terlebih dahulu hadir menuntun calon pemain untuk tertarik, mengingat kembali, atau bahkan mulai mengetahui jalan cerita game yang walaupun tidak segamblang novelnya, tetap memudahkan pemain untuk fokus terhadap tujuan bermain game WiW yang merupakan game puzzle hidden object.

Penelitian ini merupakan penelitian awal terhadap game Woman in White atau game sejenis, sehingga masih terbuka penelitian lanjutan terkait tema serupa.

\section{DAFTAR PUSTAKA}

Barthes, Roland. 2004. Mitologi (Mythologies, 1983), terj. Nurhadi \& A. Sihabul Millah. Yogyakarta. Kreasi Wacana

Big Fish Game Blog, Victorian Mysteries: Woman in White Walkthrough, 2010. http: // www.bigfishgames.com/blog/victorian-mysteries-woman-in-white-walkthrough /?af code=af6a9bc22a7d\&channel=affiliates\&identifier =af6a9bc22a7d\#0. / Diakses 1 Desembe 2010, pkl 15.30 WIB

Chandler, Daniel. 2002. Semiotics for Beginner. http://www.aber.ac.uk/media /Documents/S4B/sem-gloss.html\#M./ Diakses 21 Oktober 2010, pkl 23.05 WIB

Duranti, Krista, 2017. The legend of the Woman in White, https://exemplore.com /paranormal/The-Woman-in-White-A-Legend/ Diakses 28 Mei 2017 pkl 19.08 WIB

Gasson, Andrew. 1998 - 2010. The Woman in White, http://www.wilkie-collins. info/ boo ks_ woman_white. htm/ Diakses 5 Oktober 2010, pkl 2304 WIB

Happy Fun Communication Land. ---. Tutorial: Sign and Language. http://www.Rdillman. com/HFCL/TUTOR/Semiotics/sem4.html./ Diakses 24 Desember 2012, pkl 15.15 WIB

Miller, Ilana. ---, The Victorian Era (1837-1901) http://www.victoriaspast.com/Front Porch/victorianera.htm/ Diakses tgl 28 Mei 2017, pkl 18.50 WIB

Piliang, Yasraf A., Kartikasari Yasmin. 2010. Diktat Perkuliahan Semiotika Desain Semester Ganjil 2010/2011. Bandung. Program Magister Desain. Bandung. ITB

Santoro, Scott W. 2014, Guide to Graphic Design, Pearson Education, Amerika Serikat

Sweet, Matthew. 2014, Discovering Literature: Romantics and Victorians. https://www.bl.uk/romantics-and-victorians/articles/sensation-novels/ Diakses 25 Mei 2017, Pkl 18.44 WIB

Sobur, Alex. 2009. Semiotika Komunikasi. Bandung. PT. Remaja Rosdakarya 
Wieke Tasman - Tinjauan Game Puzzle Victorian Mysteries: Woman in White Menggunakan Pendekatan Semiotika

Tinarbuko, Sumbo, 2008. Semiotika Komunikasi Visual, Jalasutra, Yogyakarta

The MC Escher Company BV. Maurits C. Escher's Picture Gallery: Back in Holland 1941-1954.

http://www.mcescher.com/Gallery/ gallery-back.htm. Diunduh 21 Desember 2010, pk. 07.57

WIB 